\title{
NiMo/USY-Alumina Catalysts with Different Zeolite Content for Vacuum Gas Oil Hydrocracking Over Stacked Beds
}

\author{
P.P. Dik, V.P. Doronin, E.Yu. Gerasimov, M.O. Kazakov, \\ O.V. Klimov, G.I. Koryakina, K.A. Nadeina, A.S. Noskov \\ and T.P. Sorokina
}

\begin{abstract}
The stacked beds comprising hydrotreating catalyst as the top layer, hydrocracking catalyst based on amorphous silica-alumina as the interlayer and hydrocracking catalyst based on USY zeolite as the bottom layer were tested in hydrocracking of mixed feed containing straight-run VGO, heavy coker gas oil, aromatic extract and petrolatum. It is shown that stacked beds with developed catalysts can be successfully used both in the once-through hydrocracking to provide VGO conversion of 70-80\% with middle distillates yields up to $50 \mathrm{wt} \%$ and in the first stage operation of two stages hydrocracker to provide 35-65\% VGO
\end{abstract}

P.P. Dik · E.Yu. Gerasimov · M.O. Kazakov $(\bowtie) \cdot$ O.V. Klimov ·

G.I. Koryakina $\cdot$ K.A. Nadeina $\cdot$ A.S. Noskov

Boreskov Institute of Catalysis SB RAS, Novosibirsk, Russia

e-mail: kazakov@catalysis.ru

P.P. Dik

e-mail:dik@catalysis.ru

E.Yu. Gerasimov

e-mail: gerasimov@catalysis.ru

O.V. Klimov

e-mail: klm@catalysis.ru

G.I. Koryakina

e-mail: koryakina@catalysis.ru

K.A. Nadeina

e-mail: lakmallow@catalysis.ru

A.S. Noskov

e-mail: noskov@catalysis.ru

V.P. Doronin - T.P. Sorokina

Institute of Hydrocarbons Processing SB RAS, Omsk, Russia

e-mail: doronin@ihcp.ru

T.P. Sorokina

e-mail: sorokina@ihcp.ru

(C) The Author(s) 2018 
conversion and produce high-quality middle distillates and feed for the second stage. The commercial partner of this work is Gazprom Neft PJSC (Gazprom Neft Omsk Refinery).

Keywords Hydrocracking Vacuum gas oil $\cdot$ Stacked bed $\cdot$ Middle distillates Catalyst $\cdot$ Zeolite

\section{Introduction}

Hydrocracking of heavy petroleum distillates is one of the key processes in oil refinery. Hydrocracking increases oil refining efficiency and provides the production of high-quality low-sulfur middle distillates and fractions, which are used as a feed for other processes such as reforming and catalytic cracking [15]. Hydrocracking catalysts are bifunctional systems with hydrogenating and acid sites. Supported Ni-Mo(W)-S component performs hydrogenation and hydrodesulfurisation reactions, while acidic support, usually based on amorphous silica-alumina (ASA) or zeolites, performs cracking and isomerization reactions [1]. For the second stage of hydrocracking, when the feed with low-sulfur and nitrogen content (as a rule, less than $10 \mathrm{ppm}$ ) is used, Pt and Pd bifunctional catalysts may be effective [5].

Zeolite catalysts are widely used for vacuum gas oil (VGO) hydrocracking, since they are more active and allow the process to be carried out at lower temperatures. Catalysts based on ASA are less active but provide higher selectivity to middle distillates [3, 17]. Zeolite catalysts cannot be used separately for hydrocracking of non-pretreated VGO, since heteroatomic compounds, containing in non-pretreated feed, rapidly deactivate the acid function of zeolites. They should be loaded either as the bottom catalyst bed, with hydrotreating catalyst bed being on the top of the reactor in the case of layer-by-layer loading, or in the second reactor, if a hydrotreating catalyst is loaded in the first reactor [2, 11]. Hydrogenation and partial cracking of polyaromatic compounds along with transformation of nitrogen-containing compounds, which poison zeolite catalysts, occur in the first reactor or in the first catalyst bed. When a catalyst based on ASA is used separately for VGO hydrocracking, higher yield of middle distillates is achieved. However, stacked beds become more popular due to higher activity and stability and improved quality of desired products - middle distillates, particularly higher cetane number for the diesel fuels and higher smoke point for the kerosene [6, 17]. In this work, we study the influence of USY zeolite content on the properties of hydrocracking catalyst and the activity and selectivity of stacked bed in vacuum gas oil hydrocracking to achieve the maximal yield of middle distillates. The stacked bed contains hydrotreating catalyst as the top layer, hydrocracking catalyst based on amorphous aluminosilicate as the interlayer and hydrocracking catalyst based on zeolite as the bottom layer. 


\section{Experimental}

AlOOH pseudoboehmite produced by ISCZC (Russia), H-USY zeolite, obtained from microcrystalline zeolite $\mathrm{NaY}$, and amorphous aluminosilicate ASA were used for the preparation of supports. ASA was prepared by the method of sequential precipitation according to the technique described in [4]. H-USY preparation procedure included nearly complete removal of sodium ions by ammonium exchange with subsequent dealumination by thermal treatment with water vapor.

Four supports with USY content from 10 to $40 \mathrm{wt} \%$ were prepared by mixing of USY zeolite and $\mathrm{AlOOH}$ with extrusion of obtained paste using plunger extruder. The obtained trilobe extrudates were dried at $120{ }^{\circ} \mathrm{C}$ and calcined at $550{ }^{\circ} \mathrm{C}$. The $\mathrm{Al}_{2} \mathrm{O}_{3}$ and $\mathrm{ASA}-\mathrm{Al}_{2} \mathrm{O}_{3}$ supports were prepared by the same procedure.

$\mathrm{NiMo} / \mathrm{USY}(\mathrm{x})-\mathrm{Al}_{2} \mathrm{O}_{3}$ (where $\mathrm{x}$-USY zeolite content in the support) were prepared by impregnation with aqueous solution prepared from nickel carbonate, ammonium heptamolybdate and citric acid. Impregnated catalysts were dried at $120{ }^{\circ} \mathrm{C}$ and calcined at $550{ }^{\circ} \mathrm{C}$. $\mathrm{NiMo} / \mathrm{Al}_{2} \mathrm{O}_{3}$ catalyst, which was used as a first layer in a stacked bed, was prepared using similar impregnation solution but without calcination after drying at $120{ }^{\circ} \mathrm{C}$ [8]. $\mathrm{Ni}$ and $\mathrm{Mo}$ content in $\mathrm{NiMo} / \mathrm{Al}_{2} \mathrm{O}_{3}$ catalyst was 3.7 and $12.5 \mathrm{wt} \%$ respectively. BET surface area was $148 \mathrm{~m}^{2} / \mathrm{g}$ and pore volume was $0.36 \mathrm{~cm}^{3} / \mathrm{g}$ with average pore diameter of $104 \AA$. NiW/ASA$\mathrm{Al}_{2} \mathrm{O}_{3}$ catalyst, which was used as a second layer in a stacked bed, was prepared by impregnation with aqueous solution prepared from nickel carbonate, ammonium paratungstate and citric acid with subsequent drying at $120{ }^{\circ} \mathrm{C}$ and calcination at $550{ }^{\circ} \mathrm{C}$ [13]. $\mathrm{Ni}$ and $\mathrm{W}$ content in $\mathrm{NiW} / \mathrm{ASA}-\mathrm{Al}_{2} \mathrm{O}_{3}$ catalyst was 3.1 and $17.4 \mathrm{wt} \%$ respectively. BET surface area was $207 \mathrm{~m}^{2} / \mathrm{g}$ and pore volume was $0.51 \mathrm{~cm}^{3} / \mathrm{g}$.

Elemental analysis of catalysts was carried out using atomic emission spectroscopy with inductively coupled plasma on Optima 4300 DV. Textural properties of the catalysts and supports were determined by nitrogen physisorption using an ASAP 2400 Micrometrics instrument. HRTEM images were obtained on a JEM-2010 electron microscope, JEOL. Bulk crushing strength (BCS) according to Shell SMS 1471 or analogous standard ASTM method 7084-4 was measured using Bulk Crushing Strength instrument, VINCI Technologies.

Testing in hydrocracking of vacuum gasoil was carried out in a high-pressure trickle-bed unit. Catalyst trilobe granules with a length of 3-6 mm and without defects were used for reactor loading. The total volume of the catalysts in reactor was $60 \mathrm{~cm}^{3}$ : first layer-NiMo/ $\mathrm{Al}_{2} \mathrm{O}_{3} 20 \mathrm{~cm}^{3}$; second layer-NiW/ASA- $\mathrm{Al}_{2} \mathrm{O}_{3}$ $20 \mathrm{~cm}^{3}$; third layer-NiMo/USY $(\mathrm{x})-\mathrm{Al}_{2} \mathrm{O}_{3} 20 \mathrm{~cm}^{3}$. To minimize a breakthrough of the feed through a catalyst bed, catalyst granules were mixed with $\mathrm{SiC}$. A mixed feed, comprising straight-run VGO (69 wt\%), heavy coker gas oil (22 wt $\%$ ) and fractions from solvent extraction unit (aromatic extract-7 wt $\%$ ) and solvent dewaxing unit (petrolatum-2 wt\%), was used as a feed. The content of sulfur and nitrogen in the feed was 0.97 and $0.11 \mathrm{wt} \%$ respectively. Catalysts were sulfided 
in situ at a pressure of $3.5 \mathrm{MPa}$ using the mixture of straight-run gas oil, dimethyl disulfide and aniline. The catalyst loading and sulfidation procedures are thoroughly described in [6]. Hydrocracking tests were carried out at a pressure of 16.0 MPa, a liquid hourly space velocity (LHSV) of $0.71 \mathrm{~h}^{-1}$ and $\mathrm{H}_{2}$ to oil ratio of $1500(\mathrm{v} / \mathrm{v})$. The temperature in the reactor was $360{ }^{\circ} \mathrm{C}$ during the first $12 \mathrm{~h}$, and then the temperature was increased up to $390{ }^{\circ} \mathrm{C}$ and higher. Each experimental temperature (390 and $410{ }^{\circ} \mathrm{C}$ ) was maintained for $192 \mathrm{~h}$ to ensure that steady state conditions were reached. Gas effluent from the separator was analyzed by gas chromatography using FID and capillary column. Liquid products were analyzed by SIMDIS-GC in accordance with the ASTM D7213 standard test method. Product yields were defined by summing up an amount of fractions, determined by SIMDIS-GC, and an amount of fractions from the gas effluent from the separator. According to ASTM D86, liquid samples were fractioned by distillation at atmospheric pressure into naphta $\left(<130{ }^{\circ} \mathrm{C}\right)$, middle distillates $\left(130-360{ }^{\circ} \mathrm{C}\right)$ and unconverted oil $\left(>360{ }^{\circ} \mathrm{C}\right)$. Sulfur content in middle distillates was measured by ultraviolet fluorescence on Xplorer-NS, TE Instruments. The conversion and selectivity to middle distillates were calculated as in [6]. The results of catalyst testing are reported from the average of several gas and liquid product samples taken from 144 to $192 \mathrm{~h}$ on stream.

\section{Results and Discussion}

The stacked bed, which comprises a layer of zeolite catalyst, can be successfully used in the once-through VGO hydrocracking only in the case, when previous catalyst layers provide the feed quality that does not result in rapid deactivation of zeolite-containing catalyst. Accordingly, layers for preliminary hydrotreating/mild hydrocracking occupy most part of a catalyst bed, while the part of zeolite catalyst does not exceed $40 \%$ of the bed volume. To achieve the maximum yields of desired middle distillates, zeolites with low acidity should be used. Typical example of such material is dealuminated zeolite $\mathrm{Y}$ with high silica modulus [9, 17]. Zeolites with a silica modulus higher than 20 provide the optimal acidity for hydrocracking. According to the NMR data, framework $\mathrm{SiO}_{2} / \mathrm{Al}_{2} \mathrm{O}_{3}$ ratio for USY used in this work is 27.4. Thus, the USY sample is characterized by the high dealumination degree and appropriate for the preparation of hydrocracking catalysts. The internal and external surface area of USY sample is 551 and $64 \mathrm{~m}^{2} / \mathrm{g}$ respectively.

The data on particle morphology of USY sample and USY(40)- $\mathrm{Al}_{2} \mathrm{O}_{3}$ support were obtained by HRTEM (Fig. 1). The initial pseudoboehmite (HRTEM images not shown), which is used as a binder, has needle-shaped particles [7]. This morphology provides high bulk crushing strength of the obtained supports. According to HRTEM data, the USY zeolite has high crystallized particles with prismatic shape. The average crystal size of for USY zeolite less than $500 \mathrm{~nm}$ is obtained by 


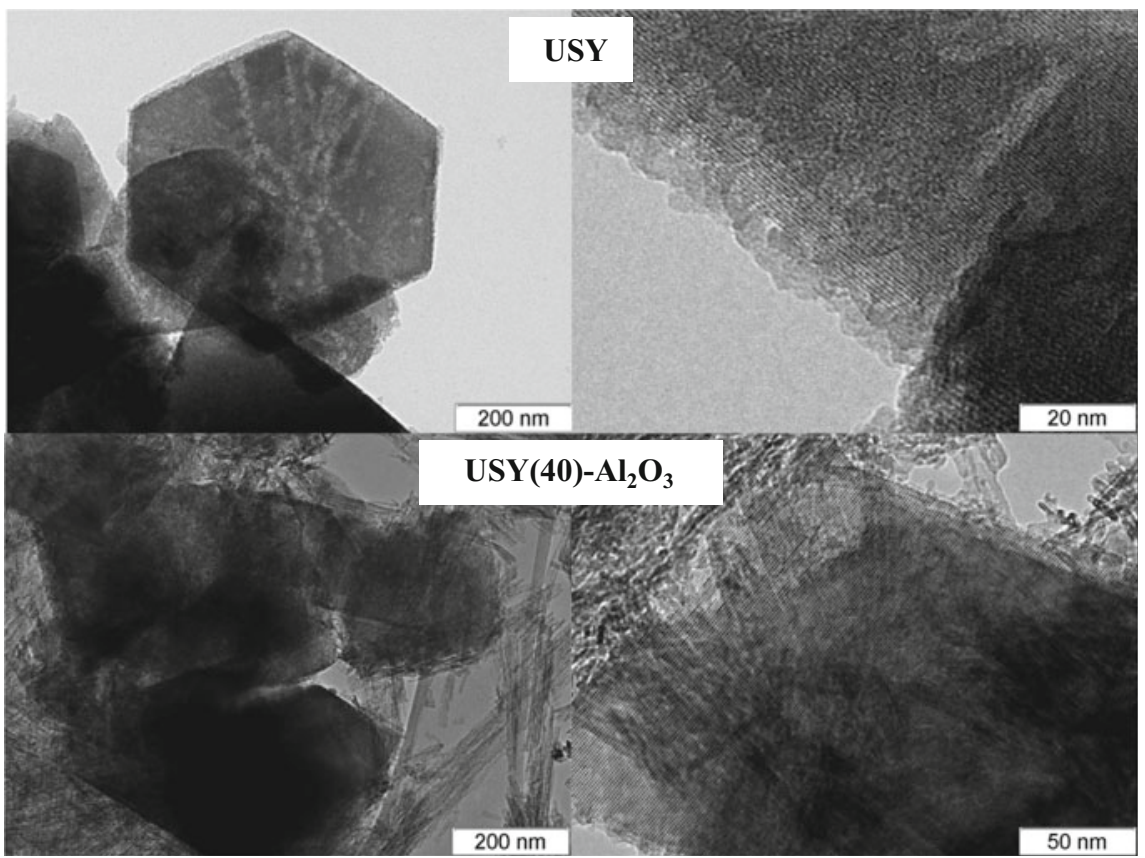

Fig. 1 HRTEM images of USY zeolite and USY(40)- $\mathrm{Al}_{2} \mathrm{O}_{3}$ support

the preparation procedure and provides low steric hindrance for bulky molecules transformation during VGO hydrocracking. Mesopores formed by framework dealumination can be observed on HRTEM images. Besides, an amorphous layer at the exterior surface of the zeolite particle is noticeable. On HRTEM images of USY (40) $-\mathrm{Al}_{2} \mathrm{O}_{3}$ support (Fig. 1) the areas related to USY zeolite and $\mathrm{Al}_{2} \mathrm{O}_{3}$ are observed. Alumina in USY(40)- $\mathrm{Al}_{2} \mathrm{O}_{3}$ support has needle-shaped particles, similar to initial pseudoboehmite [7]. The surface of zeolite crystals in the support is decorated with alumina. However, from HRTEM data it can be assumed that the zeolite morphology remains unchanged in comparison with initial zeolite powder.

The composition and textural characteristics of USY-containing supports are given in Table 1. USY- $\mathrm{Al}_{2} \mathrm{O}_{3}$ supports have high surface area-higher than

Table 1 Composition and textural characteristics of $\mathrm{USY}-\mathrm{Al}_{2} \mathrm{O}_{3}$ supports

\begin{tabular}{l|l|l|l|l}
\hline Characteristic & $\begin{array}{l}\text { USY(10)- } \\
\mathrm{Al}_{2} \mathrm{O}_{3}\end{array}$ & $\begin{array}{l}\mathrm{USY}(20)- \\
\mathrm{Al}_{2} \mathrm{O}_{3}\end{array}$ & $\begin{array}{l}\mathrm{USY}(30)- \\
\mathrm{Al}_{2} \mathrm{O}_{3}\end{array}$ & $\begin{array}{l}\mathrm{USY}(40)- \\
\mathrm{Al}_{2} \mathrm{O}_{3}\end{array}$ \\
\hline USY content, wt\% & 10 & 20 & 30 & 40 \\
\hline $\begin{array}{l}\text { BET surface area } \\
\left(\mathrm{m}^{2} / \mathrm{g}\right)\end{array}$ & 253 & 275 & 301 & 351 \\
\hline Pore volume $\left(\mathrm{cm}^{3} / \mathrm{g}\right)$ & 0.54 & 0.50 & 0.50 & 0.52 \\
\hline
\end{tabular}


$250 \mathrm{~m}^{2} / \mathrm{g}$. The increase of USY content provides proportional increase of support surface area. It can be supposed that there is no formation of new phases and $\mathrm{Al}_{2} \mathrm{O}_{3}$ and USY present in support as individual phases. This result in good agreement with HRTEM data. The pore volume of all supports is similar.

The elemental analysis data, textural characteristics and bulk crushing strength of the catalysts are given in Table 2 . In all the cases the catalysts with the bulk crushing strength higher than 1.2 MPa were obtained. This value is sufficient for industrial application. Incorporation of $\mathrm{Ni}$ and $\mathrm{Mo}$ in the supports leads to the decrease of the surface area by $46-71 \mathrm{~m}^{2} / \mathrm{g}$ comparing with the initial support. The pore volume of all catalysts is similar and from 0.08 to $0.16 \mathrm{~cm}^{3} / \mathrm{g}$ lower than the pore volume of corresponding supports.

Nitrogen adsorption-desorption isotherms for the supports are attributed to pseudo-type II isotherms with hysteresis loops of type H3 [16]. The adsorption-desorption isotherms have narrow hysteresis loop, which indicates the wide pore size distribution in the supports. The increase of zeolite content in the support virtually have no influence on the form of adsorption-desorption isotherms and hysteresis loops. Nitrogen adsorption-desorption isotherms for the catalysts have similar form as for the supports. The increase of the width of hysteresis loops at $\mathrm{P} / \mathrm{P}^{0}=0.4-0.6$ indicates the presence of micropores in the obtained catalysts.

Pore size distributions of the USY $-\mathrm{Al}_{2} \mathrm{O}_{3}$ supports in comparison with corresponding NiMo catalysts are shown in Fig. 2. The assessment of the pore size distribution was made by adsorption branch of isotherm, since no plateau is apparent at high $\mathrm{P} / \mathrm{P}^{0}$. The obtained supports have similar pore size distribution. The supports are characterized by bimodal pore size distribution with pores of less than $4 \mathrm{~nm}$ diameter and mesopores with 4-25 $\mathrm{nm}$ diameter.

Preparation of catalysts using citric acid prevents undesirable penetration of metals in narrow pores of a support, thus active component is localized in pores with diameter higher than $5 \mathrm{~nm}$ [12]. According to obtained results, supported metals are preferentially localized in the pores with diameters higher than $6 \mathrm{~nm}$ (Fig. 2). It is confirmed by the decrease of the volume of these pores after supporting of $\mathrm{Ni}$ and Mo. As it was observed previously [6], the catalyst preparation

Table 2 Composition and properties of $\mathrm{NiMo} / \mathrm{USY}-\mathrm{Al}_{2} \mathrm{O}_{3}$ catalysts

\begin{tabular}{l|l|l|l|l}
\hline Characteristic & $\begin{array}{l}\mathrm{NiMo} / \mathrm{USY} \\
(10)-\mathrm{Al}_{2} \mathrm{O}_{3}\end{array}$ & $\begin{array}{l}\mathrm{NiMo} / \mathrm{USY} \\
(20)-\mathrm{Al}_{2} \mathrm{O}_{3}\end{array}$ & $\begin{array}{l}\mathrm{NiMo} / \mathrm{USY} \\
(30)-\mathrm{Al}_{2} \mathrm{O}_{3}\end{array}$ & $\begin{array}{l}\mathrm{NiMo} / \mathrm{USY} \\
(40)-\mathrm{Al}_{2} \mathrm{O}_{3}\end{array}$ \\
\hline $\mathrm{Ni}(\mathrm{wt} \%)$ & 2.1 & 2.9 & 2.8 & 2.6 \\
\hline Mo $(\mathrm{wt} \%)$ & 7.2 & 9.7 & 9.0 & 8.7 \\
\hline BET surface $a r e a\left(\mathrm{~m}^{2} / \mathrm{g}\right)$ & 190 & 204 & 255 & 288 \\
\hline Pore volume $\left(\mathrm{cm}^{3} / \mathrm{g}\right)$ & 0.41 & 0.40 & 0.42 & 0.36 \\
\hline BCS $(\mathrm{MPa})$ & 1.3 & 1.4 & 1.2 & 1.2 \\
\hline
\end{tabular}



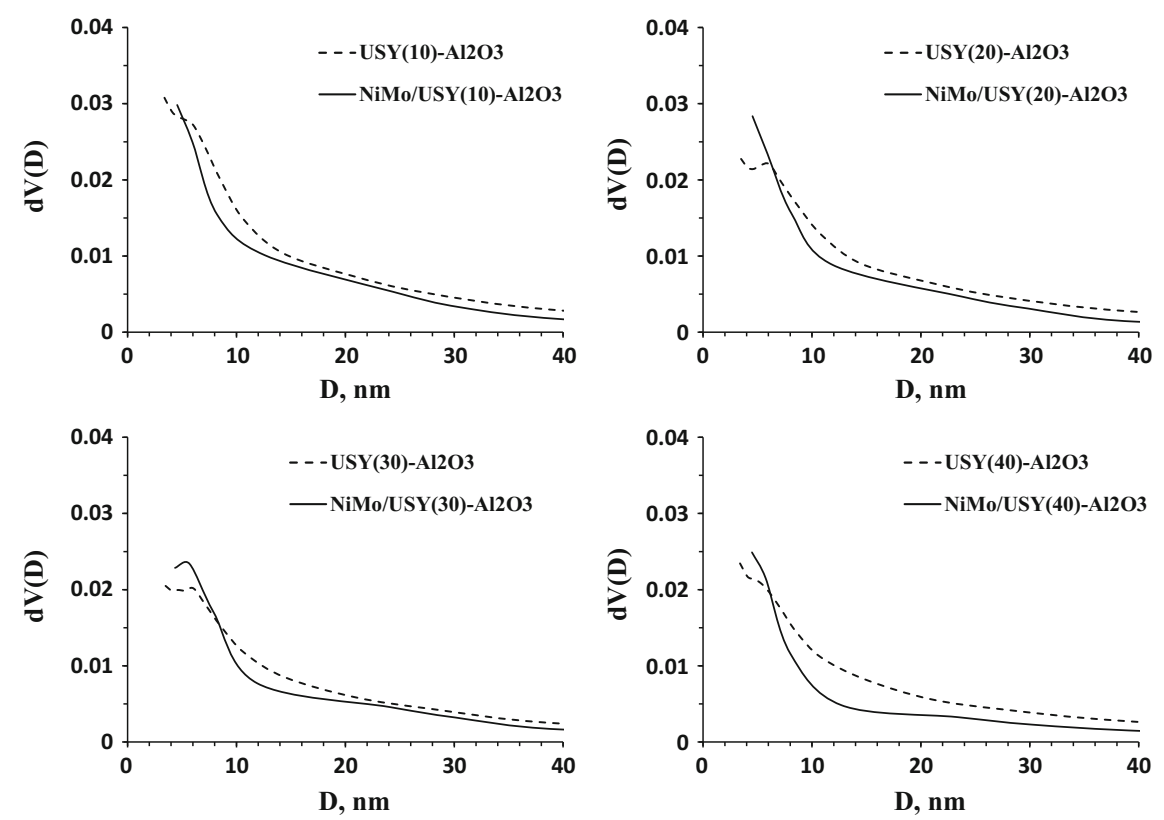

Fig. 2 Pore size distribution in the $\mathrm{USY}-\mathrm{Al}_{2} \mathrm{O}_{3}$ supports and $\mathrm{NiMo} / \mathrm{USY}-\mathrm{Al}_{2} \mathrm{O}_{3}$ catalysts

Table 3 The results of VGO hydrocracking-product yield and sulfur content in middle distillates

\begin{tabular}{|c|c|c|c|c|c|c|c|c|}
\hline \multirow{2}{*}{$\begin{array}{l}\text { Sample } \\
\text { Temperature }\left({ }^{\circ} \mathrm{C}\right) \\
\end{array}$} & \multicolumn{2}{|c|}{$\begin{array}{l}\mathrm{NiMo} / \mathrm{USY} \\
(10)-\mathrm{Al}_{2} \mathrm{O}_{3}\end{array}$} & \multicolumn{2}{|c|}{$\begin{array}{l}\mathrm{NiMo} / \mathrm{USY} \\
(20)-\mathrm{Al}_{2} \mathrm{O}_{3}\end{array}$} & \multicolumn{2}{|c|}{$\begin{array}{l}\mathrm{NiMo} / \mathrm{USY} \\
(30)-\mathrm{Al}_{2} \mathrm{O}_{3}\end{array}$} & \multicolumn{2}{|c|}{$\begin{array}{l}\mathrm{NiMo} / \mathrm{USY} \\
(40)-\mathrm{Al}_{2} \mathrm{O}_{3}\end{array}$} \\
\hline & 390 & 410 & 390 & 410 & 390 & 410 & 390 & 410 \\
\hline Gas $(w t \%)$ & 0.1 & 2.8 & 0.4 & 4.0 & 0.5 & 5.4 & 1.0 & 8.4 \\
\hline Naphta $<130{ }^{\circ} \mathrm{C}(\mathrm{wt} \%)$ & 0.7 & 8.9 & 1.6 & 16.8 & 1.4 & 23.4 & 4.7 & 32.6 \\
\hline Middle distillates $130-360{ }^{\circ} \mathrm{C}(\mathrm{wt} \%)$ & 28.0 & 43.9 & 29.4 & 47.3 & 25.8 & 44.9 & 31.6 & 46.5 \\
\hline Unconverted oil $>360^{\circ} \mathrm{C}(\mathrm{wt} \%)$ & 71.2 & 44.3 & 68.6 & 31.9 & 72.3 & 26.3 & 62.8 & 12.6 \\
\hline $\mathrm{S}$ in middle distillates $(\mathrm{wt} \%)$ & 11 & 9 & 9 & 6 & 10 & 8 & 12 & 7 \\
\hline
\end{tabular}

method, used in this work, provides preferential localization of $\mathrm{Ni}$ and Mo on $\mathrm{Al}_{2} \mathrm{O}_{3}$, with most part of the surface and volume of zeolite pores to be free and available for catalysis.

Stacked beds containing three catalysts: $\mathrm{NiMo} / \mathrm{Al}_{2} \mathrm{O}_{3}, \mathrm{NiW} / \mathrm{ASA}-\mathrm{Al}_{2} \mathrm{O}_{3}$ and $\mathrm{NiMo} / \mathrm{USY}(\mathrm{x})-\mathrm{Al}_{2} \mathrm{O}_{3}$ were tested in VGO hydrocracking. Weight yields of each fraction and sulfur content in the middle distillates are given in Table 3. The dependence of selectivity to middle distillates on conversion of VGO is shown in Fig. 3. Selectivity to middle distillates was referred to the fraction $130-360{ }^{\circ} \mathrm{C}$ in the product mixture. 
Fig. 3 Selectivity to middle distillates as a function from VGO conversion

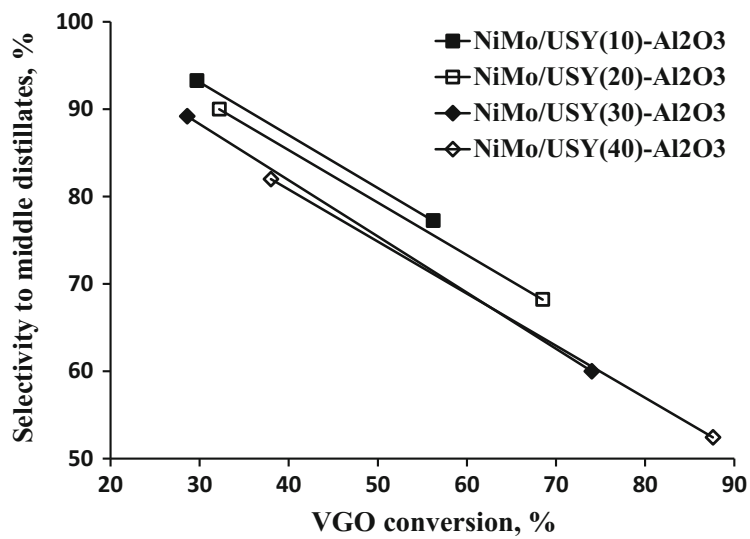

The conversion of VGO at $390{ }^{\circ} \mathrm{C}$ was between 29 and $38 \mathrm{wt} \%$ for all catalysts and middle distillates yield did not exceed $32 \mathrm{wt} \%$. Increase of the process temperature to $410{ }^{\circ} \mathrm{C}$ leads to the significant increase of VGO conversion and middle distillates yield. However, toughening of hydrocracking process conditions inevitably results in undesirable gas formation. This effect was more pronounced for the catalysts with higher USY content, which have lower selectivity. In our case NiMo/ USY(10)- $\mathrm{Al}_{2} \mathrm{O}_{3}$ catalyst, containing $10 \mathrm{wt} \%$ of USY in the support, showed the highest selectivity to middle distillates (Fig. 3) at minimal gas formation (Table 3). However, VGO conversion was the lowest: at $410{ }^{\circ} \mathrm{C}$ VGO conversion was less than $60 \%$. Comparing properties of hydrocracking catalysts at higher temperatures is not reasonable because of significant increase of thermal (non-catalytic) cracking rate [14] and deactivation rate of catalysts [10]. Besides, when the zeolite content of the hydrocracking catalyst is relatively low $(<15 \mathrm{wt} \%)$, the non-zeolitic component of the catalyst can have a substantial impact on activity and selectivity [17].

The highest conversion of $88 \%$ was achieved on the catalyst with maximum USY content. At the same time the selectivity to middle distillates was the lowest and gas yield was more than $8 \mathrm{wt} \%$. Although, VGO conversion on NiMo/USY (20) $-\mathrm{Al}_{2} \mathrm{O}_{3}$ catalyst was lower than on the catalysts with higher zeolite content at the same hydrocracking temperature, the middle distillates yield was slightly higher and exceeded $47 \mathrm{wt} \%$ at temperature of $410{ }^{\circ} \mathrm{C}$ along with reasonable gas formation (Table 3 ). It should be noted that the middle distillate fraction yield did not exceed $50 \mathrm{wt} \%$ for all stacked beds with zeolite-containing catalysts because increase of VGO conversion is accompanied by the increase of gas and naphta yield and drastic decrease of selectivity of $\mathrm{NiMo} / \mathrm{USY}-\mathrm{Al}_{2} \mathrm{O}_{3}$ catalysts. Sulfur content in the obtained middle distillate fractions did not exceed $10 \mathrm{ppm}$ at $410{ }^{\circ} \mathrm{C}$ process temperature and was between 9 and $12 \mathrm{ppm}$ for $390{ }^{\circ} \mathrm{C}$ (Table 3). 


\section{Conclusions}

$\mathrm{NiMo} / \mathrm{USY}-\mathrm{Al}_{2} \mathrm{O}_{3}$ catalysts with different zeolite content, $\mathrm{NiMo} / \mathrm{Al}_{2} \mathrm{O}_{3}$ and $\mathrm{NiW} /$ $\mathrm{ASA}-\mathrm{Al}_{2} \mathrm{O}_{3}$ catalysts were prepared by impregnation of shaped supports with solutions containing precursors of active metals and citric acid. The catalysts were tested in hydrocracking in the form of stacked beds, where layers containing hydrotreating catalyst $\left(\mathrm{NiMo} / \mathrm{Al}_{2} \mathrm{O}_{3}\right)$ and hydrocracking catalyst based on amorphous aluminosilicate $\left(\mathrm{NiW} / \mathrm{ASA}-\mathrm{Al}_{2} \mathrm{O}_{3}\right)$ were loaded before the layer of zeolite catalyst. NiMo/USY(10)- $\mathrm{Al}_{2} \mathrm{O}_{3}$ catalyst, containing $10 \mathrm{wt} \%$ of USY in the support, was established to have the highest selectivity to middle distillates, however the activity in hydrocracking is insufficient. The highest yield of middle distillates was obtained at temperature of $410{ }^{\circ} \mathrm{C}$ on $\mathrm{NiMo} / \mathrm{USY}(20)-\mathrm{Al}_{2} \mathrm{O}_{3}$ catalyst. Sulfur content in the obtained middle distillate fractions was from 9 to $12 \mathrm{ppm}$ at $390{ }^{\circ} \mathrm{C}$ process temperature and from 6 to $9 \mathrm{ppm}$ at $410{ }^{\circ} \mathrm{C}$. Stacked beds with developed catalysts can be successfully used in the once-through hydrocracking to provide VGO conversion of 70-80\% and middle distillates yields up to $50 \mathrm{wt} \%$. Besides, such stacked beds can be used in the first stage operation of two stages hydrocracker to provide $35-65 \%$ VGO conversion and produce high-quality middle distillates and feed for the second stage.

Acknowledgements Research are carried out with the financial support of the state represented by the Ministry of Education and Science of the Russian Federation. Agreement no. 14.610.21.0008 11 Aug 2015. Unique project Identifier: RFMEFI61015X0008.

\section{References}

1. Alsobaai, A.M., Zakaria, R., Hameed, B.H.: Gas oil hydrocracking on NiW/USY catalyst: Effect of tungsten and nickel loading. Chem. Eng. J. 132, 77-83 (2007)

2. Alvarez, A., Ancheyta, J.: Simulation and analysis of different quenching alternatives for an industrial vacuum gasoil hydrotreater. Chem. Eng. Sci. 63, 662-673 (2008)

3. Corma, A., Martínez, A., Martínez-Soria, V.: Catalytic performance of the new delaminated ITQ-2 zeolite for mild hydrocracking and aromatic hydrogenation. J. Catal. 200, 259-269 (2001)

4. Dik, P.P., Klimov, O.V., Budukva, S.V., Leonova, K.A., Pereyma, V.Yu., Gerasimov, E.Yu., Danilova, I.G., Noskov, A.S.: Silica-alumina based nickel-molybdenum catalysts for vacuum gas oil hydrocracking aimed at a higher diesel fraction yield. Catal. Ind. 6, 231-238 (2014)

5. Dik, P.P., Klimov, O.V., Danilova, I.G., Leonova, K.A., Pereyma, V.Yu., Budukva, S.V., Uvarkina, D.D., Kazakov, M.O., Noskov, A.S.: Hydroprocessing of hydrocracker bottom on Pd containing bifunctional catalysts. Catal. Today 271, 154-162 (2016)

6. Dik, P.P., Klimov, O.V., Koryakina, G.I., Leonova, K.A., Pereyma, V.Yu., Budukva, S.V., Gerasimov, E.Yu., Noskov, A.S.: Composition of stacked bed for VGO hydrocracking with maximum diesel yield. Catal. Today 220-222, 124-132 (2014)

7. Klimov, O.V., Leonova, K.A., Koryakina, G.I., Gerasimov, E.Yu., Prosvirin, I.P., Cherepanova, S.V., Budukva, S.V., Pereyma, V.Yu., Dik, P.P., Parakhin, O.A., Noskov, A.S.: Supported on alumina Co-Mo hydrotreating catalysts: dependence of catalytic and 
strength characteristics on the initial AlOOH particle morphology. Catal. Today 220-222, 6677 (2014)

8. Klimov, O.V., Nadeina, K.A., Dik, P.P., Koryakina, G.I., Pereyma, V.Yu., Kazakov, M.O., Budukva, S.V., Gerasimov, E.Yu., Prosvirin, I.P., Kochubey, D.I., Noskov, A.S.: CoNiMo/ $\mathrm{Al}_{2} \mathrm{O}_{3}$ catalysts for deep hydrotreatment of vacuum gasoil. Catal. Today 271, 56-63 (2016)

9. Martinez, C., Corma, A.: Inorganic molecular sieves: preparation, modification and industrial application in catalytic processes. Coord. Chem. Rev. 255, 1558-1580 (2011)

10. Martínez, J., Ancheyta, J.: Kinetic model for hydrocracking of heavy oil in a CSTR involving short term catalyst deactivation. Fuel 100, 193-199 (2012)

11. Nishijima, A., Sato, T., Yoshimura, Y., Shimada, H., Matsubayashi, N., Imamura, M., Sugimoto, Y., Kameoka, T., Nishimura, Y.: Two stage upgrading of middle and heavy distillates over newly prepared catalysts. Catal. Today 27, 129-135 (1996)

12. Pashigreva, A.V., Klimov, O.V., Bukhtiyarova, G.A., Fedotov, M.A., Kochubey, D.I., Chesalov, Y.A., Zaikovskii, V.I., Prosvirin, I.P., Noskov, A.S.: The superior activity of the CoMo hydrotreating catalysts, prepared using citric acid: what's the reason? Stud. Surf. Sci. Catal. 175, 109-116 (2010)

13. Pereyma, V.Yu., Dik, P.P., Klimov, O.V., Budukva, S.V., Leonova, K.A., Noskov, A.S.: Hydrocracking of vacuum gas oil in the presence of catalysts $\mathrm{NiMo} / \mathrm{Al}_{2} \mathrm{O}_{3}$-amorphous aluminosilicates and $\mathrm{NiW} / \mathrm{Al}_{2} \mathrm{O}_{3}$-amorphous aluminosilicates. Russ. J. Appl. Chem. 88, 1969-1975 (2015)

14. Ramírez, S., Martínez, J., Ancheyta, J.: Kinetics of thermal hydrocracking of heavy oils under moderate hydroprocessing reaction conditions. Fuel 110, 83-88 (2013)

15. Stanislaus, A., Marafi, A.: Recent advances in the science and technology of ultra low sulfur diesel (ULSD) production. Catal. Today 153, 1-68 (2010)

16. Thommes, M., Kaneko, K., Neimark, A.V., Olivier, J.P., Rodriguez-Reinoso, F., Rouquerol, J., Sing, K.S.W.: Physisorption of gases, with special reference to the evaluation of surface area and pore size distribution (IUPAC Technical Report). Pure Appl. Chem. 87, 1052-1069 (2015)

17. Ward, J.W.: Hydrocracking processes and catalysts. Fuel Process. Technol. 35, 55-85 (1993)

Open Access This chapter is licensed under the terms of the Creative Commons Attribution 4.0 International License (http://creativecommons.org/licenses/by/4.0/), which permits use, sharing, adaptation, distribution and reproduction in any medium or format, as long as you give appropriate credit to the original author(s) and the source, provide a link to the Creative Commons license and indicate if changes were made.

The images or other third party material in this chapter are included in the chapter's Creative Commons license, unless indicated otherwise in a credit line to the material. If material is not included in the chapter's Creative Commons license and your intended use is not permitted by statutory regulation or exceeds the permitted use, you will need to obtain permission directly from the copyright holder.

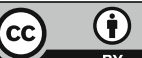

